\title{
Emotional and Entrepreneurial Didactics for Sustainable Design Educations
}

\author{
AINOA ABELLA GARCIA, THOMAS $\varnothing$ STERGAARD \& MARIA JOSÉ ARAYA ${ }^{1}$
}

\begin{abstract}
Students at Higher Educations face a world in need of help to create sustainable solutions for complex systems. But still, European design-graduates finish their studies with a narrow concentration in design skills and lack competencies in order to cope with the complex reality, as well as students lack attachment to the teaching in Education for Sustainable Development (ESD). In order to change this, educators need to acknowledge the students' personal, motivational and emotional elements before designing the courses. This article is based on two new discourses in both entrepreneurial and design didactic research - and how they could be connected. The first is "emotional learning" and "emotional design" - regarding how emotions impact the student's learning process' in Educations for Sustainable Development (ESD). Emotions affect the student's learning process and their health and well-being (Pekrun, 2014, p. 28). The other discourse is how the use of value-driven emotional entrepreneurial didactics, based on the connection between emotionally influencing actions/events and the development of entrepreneurial competencies, can present a new emotionally based understanding of the value of altruistic (sustainable) outcomes within entrepreneurial educations (Lackeus, 2020). This paper presents, using one of the experimental methods -comparative- of Research through Design, two emotional tools: "Design for Change - Yggdrasill" from VIA Design, Denmark and "Emotional Analogous Data" from ELISAVA, Barcelona. The first results indicate a need for emotional education, which has an impact on ESD and their development as professionals. For these reasons, both emotional tools presented above can contribute to empowering students and teachers to improve Sustainable Design Educations.
\end{abstract}

KEYWORDS: Design Education; Design Didactics; Education for Sustainable Development (ESD); Emotional Learning; Value Creation Entrepreneurship Education

1 The authors would like to thank ELISAVA, Barcelona School of Design and Engineering (Faculty of Design of the University of Vic - Central University of Catalonia) and VIA Design, Denmark, for making the collaboration possible. 


\section{Introduction}

Teaching at design-schools and universities is still very often shaped by disciplinary structures and silos. Research in Education for Sustainable Development has shown this has very little effort if the students are to cope with complex challenges. (UNESCO, 2018) So, the anomaly between UNESCO wishes for the future of education and the real educational world needs to be addressed in research, practice and learning at Higher Educations. But educators are often challenged by several major questions before developing a framework for an ESD course; what are the competences needed, - should the course involve all competences, how committed are the students and how can they become involved, what didactical frameworks could be adapted and how can it be provided? (Frisk \& Larsson, 2011; UNESCO, 2017; Østergaard, 2019, p. 18). Success in acquiring sustainability competencies extends beyond memorisation and requires educational institutions to provide new in-formal learning settings with a focus on generating an "action-oriented entrepreneurial mindset" (Rieckmann, 2012). But, as competencies are descriptive for a person's capability of acting, competencies do not ensure action of the intended competency. So, how can we ensure motivation and emotional commitment for acting on the challenges we meet? As the fundamentals of the ESD are primarily ethical and moral, this gives the student the possibility to acquire personal insight and can enable an emotional and spiritual awareness.

Implementing ESD's in higher education institutions actually offers educational designers the possibility of rethinking the didactic approaches in order to develop new disciplinary ESD knowledge, competencies, experiences, and motivation. The "how" of the students are being taught in order to prepare students for shaping a sustainable future becomes central. ESD's can challenge the teacher as well as the student's values and self-perception at the most intimate and emotional level. ESD requires a shift in consciousness, which can be seen as a deeply challenging effort for students and teachers, at such a deep level that new formations of self can become apparent and integrated into the student's identity. (Ploum, et al., 2018)

The two methods and cases described, The Yggdrasill Box and the Emotional Analogous Data, offer innovations to the concept of ESD with an emphasis on developing non-formal intrapersonal competencies used in an iterative, active learning cycle with a focus on emotional learning, personal awareness and entrepreneurial action. But, working with intrapersonal competencies can be very challenging for both educators and learners. And, as this is a new land of education, we still have to progress slowly and with caution. When dealing with people and emotions, things might get tough, sometimes.

Some of the fundamental challenges in designing ESD's are related to engaging the student, to do so, the authors of this paper believe that ESD's are needed as well, as the paper accepts the need for radical societal changes and the need for motivating and giving the students insight and competencies to make the change happen through self-reflection, awareness and action. This study attempts to understand how emotions are detected and used during the learning process, how this could affect or be related to ESD through different emotional tools based on Research through Design methodologies. Tools, such as those presented in this paper, hopefully, increase the dynamisation and reduce the distance between emotional commitment and the educators and students in the process. 


\section{State of the Art}

\section{Sustainable Key Competencies and the need for action.}

This paper aligns its approach with previous extensive work on developing frameworks for key competencies as done by Wiek (2011), Barth (2012), Bieberhofer (2017) and UNESCO (2018), but the need for additional key competencies supporting intrapersonal transformation, as suggested by Vare et al. (2019) and action-based sustainability competencies, proposed by Lans et al. (2014), Ploum et al. (2018) and Bieberhofer (2019) are required.

A definition of competences relies on an interlinked complex of knowledge, skills, and attitudes -emotions- that enables the performance of successful tasks and problem solving (Wiek,et al. 2010). Competencies should be differentiated from learning outcomes (e.g., for curriculum development). Wiek et al. (2011: 204) defined five basic key competencies for ESD's. The five sustainability key competencies are described as: systems thinking, anticipatory thinking, normative thinking, strategic thinking, and interpersonal competencies. By using non-cognitive emotional elements of education is a definition of key-competencies could be defined as "the ability to successfully meet complex demands in a particular context through the mobilisation of psychosocial prerequisites -including cognitive and noncognitive aspects-" (Rychen, 2003). Competencies capture the sense not only of acquiring but also of producing knowledge, embracing different ways of knowing and avoiding a narrow focus on specific skills. (Ibid) Non-cognitive competencies interact with cognition and can be developed over time; as Vare et al. (2019) explain, competence is a quality developed through practice and not an end state. Even if it may seem difficult to describe intangible outcomes as emotional or affective responses, recent research competency frameworks now have a high focus on the aspects of interpersonal competencies. Competences are often verbs, emphasising the need to do. Giangrande, et al., (2019) describes the need for action as a question of redefining the didactic approaches and focusing on enabling the students to understand and act upon their underlying values and motivational drivers.

\section{The role and the implications of emotions}

An emotion is a mental state, which is spontaneous and short-lived; it can vary from seconds to minutes (Abella et al., 2020). It is an involuntary impulse responding to stimuli from the environment that causes either a positive or a negative psychological response; for this reason, emotions were and have been a dimension of constant interest and subject of research. The main reason is that they play a fundamental role in the development of any human activity since they positively and/or negatively influence how human beings develop and impact their well-being or discomfort (Rodrigo-Ruiz, 2016), from pleasure to displeasure.

In teaching and learning activities, it has become an object of analysis since the universe of emotions that students experience affects both their development and health as well as their performance and how they face different academic situations. Therefore, it is necessary to deepen our understanding of the emotions that students feel in educational contexts (Larruzea-Urkixo, Cardeñoso, \& Mondragon, 2020).

As there are different theories about emotions and their classification (Ortony \& Turner, 1990), it is necessary to frame the project in those that allow students to identify and define emotions more easily. For example, the one selected for this research is based on five basic emotions: happy, disgust, sad, angry and fear (Oatley \& Johnson-Laird, 1987).

If a learning experience includes or carries emotional components, the brain stores this new experience and knowledge better because it is interpreted as a key element for survival, and therefore later allows it to be used more efficiently (Bueno, 2017). All these emotions - 
pleasure, joy, fear, among others- have important effects on students on their learning process, their goals, and their achievements. The main reason is that emotions control in different ways the attention, motivation, selection of the personal learning style and strategy, and affect the personal self-regulation of learning (Pekrun, 2014, p. 8). Some authors have detected and researched the specific emotions that are related to academic tasks, and it may be relevant to consider for student's learning: achievement emotions, epistemic emotions, topic emotions and social emotions (Pekrun, 2014, p. 8).

It is necessary to investigate from a multidisciplinary perspective since the studies that have been found focus on certain careers, such as psychology, education, and languages. The need for exploration in other areas has been detected, like design, engineering, architecture and entrepreneurship, among other creative fields. In these areas, autonomous learning is made, and that is one of the main reasons for including emotional intelligence in the study programs (Larruzea-Urkixo, Cardeñoso, \& Mondragon, 2020).

Through learning and implementation of emotions in designs, users can improve, understand, and feel more related to the actual situation and its consequences (Abella, Cléries \& Marco-Almagro, 2019). For that reason, there is an important and interesting challenge to understand how designers can implement emotions in their designs to promote better learning and practice of the sustainable development goals, using some theories such as Emotionally Durable Design (Chapman, 2015,p. 18).

There are three main actions related to sustainability: the decision-making process, empathising with current problems, and accelerating new values. Emotions have a crucial role in decision-making and product acquisition. In the final decision process, when the user is faced with the doubt of choosing correctly, emotions intervene and help the process (Abella, Cléries \& Marco-Almagro, 2019). So, emotions can influence the final decision to purchase more according to and considering the impact on the short, medium, and long term that the product, service, or experience will have. Also, emotions can influence and affect the process of empathising with current problems, such as social and environmental ones (Batson et al., 1981). Emotions and values are intertwined with consumption and, therefore, are associated with consumer behaviours. (Laverie et al.,1993). In view of the above, it is essential to understand which methods and tools are relevant in the framework of this proposal related to sustainability.

\section{The co-relations between Design and Entrepreneurship.}

Both at ELISAVA and at VIA Design students are a mix of designers, entrepreneurs, engineers and come from other disciplines. At both institutions, Sustainable Development is being implemented into the curriculum and revisions of both design disciplines and entrepreneur definitions are being made. The two disciplines represented in this article, design and entrepreneurship, derive from two very different research fields. One -design- is primarily based on artistic, creative, experimentation and intuition research methods and practices, whereas the other -entrepreneurship- originally derives from the field of social science, business and causal prediction.

The act of designing is defined by the capability of visualising through the use of personal skills manipulating different materials. The process of designing requires a variety of processing skills. The design process demands both communicative skills, being intuitive, empathetic, creative and capable of thinking deconstructive, holistic, iterative, divergent and convergent. On top of this a designer often has to have a human-centered approach, trying to visualise, map or frame the user-mind, capture experiences and prototype these with the user. (Stickdorn et al. 2018; Wetter-Edmann, 2011). Even so, designers are often considered 
to become natural entrepreneurs, due to their creative and innovative product development competences. Some studies claim creative professionals to be more likely to become self-employed entrepreneurs or intrapreneurs. (Kortzfleisch et al., 2013)

According to Shane \& Venkatamaran (2000), entrepreneurs discover, evaluate and exploit opportunities, whereas the designers identify the problem, ideate and generate solutions with and for the customer or users. In a service design approach, practices are often described as co-creational involving other professions and non-designers in the idea-generating process, using methods and participatory facilitation methods. (Stickdorn et al., 2018) In this sense, the scope of the process can become how the actors relate in the value creation (Stickdorn et al., 2018). Service Design has been used as an asset for fields other than design. It has gained attraction in the business, leadership and management sectors, amongst others, to cope with increasing complexity and to use it as a driver of innovation and business success (Ibid).

Also, Sarasvathy (2008) describes how entrepreneurs become designers and vice versa as they design concepts; business, cultural, commercial or social services, organisations or even markets and how these "artifacts" - ideas, products, services can define and thereby produce new environments or realities. All this is often done by using team-based, multidisciplinary approaches to problem-solving with a high focus on user or human-centered aspects. And the notion of "creativity" connects the two disciplines. To the entrepreneur, creativity is often described as the ability to see opportunities or unknown solutions, markets and users, whereas to the designer, creativity is the capacity of seeing new things, artefacts, services, users-needs, patterns and solutions. You could say creativity is the intersection between design and entrepreneurship and the main similarity between the two disciplines. At the same level, both entrepreneurs and designers rely strongly on the use of empathy in order to understand their collaborating partners, future customers, users or shareholders. Value Business Modelling, Empathy Cards or Customer Journeys are often used methodologies amongst entrepreneurs in order to better construe the true needs - the pains and the gains - and the customer jobs to be done. (Osterwalder, 2019) Designers may be using the same empathetic methodologies in mapping and imagining and trying to understand the future users' -humanneeds (Brown, 2008; Stickdorn et al. 2018). Both disciplines are also working in highly uncertain and unpredictable settings (Sarasvathy, 2008) with a high grade of complexity and wicked problems (Buchanan, 1992), which influences and challenges their behaviour, thoughts, emotions and actions. (Kortzfleisch et al., 2013)

When comparing the ESD-discourse description of sustainable competencies we found a lot of overlapping incidents. Keeping in mind how theory urges to be used, it makes sense to develop new emotional and entrepreneurial ESD courses. 


\begin{tabular}{|c|c|c|}
\hline $\begin{array}{l}\text { Key Competencies for } \\
\text { Sustainable Development }\end{array}$ & $\begin{array}{l}\text { Entrepreneurship } \\
\text { Competencies }\end{array}$ & $\begin{array}{l}\text { Litterature ESD \& } \\
\text { Entrepreneurship }\end{array}$ \\
\hline $\begin{array}{l}\text { SystemThinking } \\
\text { Ability to understand patterns } \\
\text { systems and complexity in } \\
\text { sub-systems and multiple } \\
\text { variables and resilience }\end{array}$ & $\begin{array}{l}\text { Social and cultural competency } \\
\text { to be able to collaborate or } \\
\text { understand context and culture in } \\
\text { a given social reality }\end{array}$ & $\begin{array}{l}\text { Entrepreneurship: Nielsen et al. } \\
\text { 2009, Darsø 2011, FFE, 2013, } \\
\text { Sarasvathy, 2001a, 2001b, 2008, } \\
\text { ESD-discourse; Wiek et al. 2011, } \\
\text { Bieberhofer, 2019, Vare et al, 2006, } \\
\text { Giangrande, et al. 2019, UNESCO, } \\
\text { 2019, Ploum, et al., } 2017\end{array}$ \\
\hline $\begin{array}{l}\text { Strategic Competencies } \\
\text { Strategies,awarenessofsuccessfactors } \\
\text { Decisionmaking } \\
\text { obstaclestochange,knowledgeof } \\
\text { behaviouralchange,organisational } \\
\text { developmentskills }\end{array}$ & $\begin{array}{l}\text { Strategic Competencies } \\
\text { The ability to analyze and } \\
\text { understand how Business } \\
\text { development and business } \\
\text { modelling, user and customerjour- } \\
\text { neys can make ideas prevail, } \\
\text { go-to-market, etc. }\end{array}$ & $\begin{array}{l}\text { Entrepreneurship: Sarasvathy, } \\
2001 \mathrm{a}, 2001 \mathrm{~b}, 2008 \text {, Blenker et al. } \\
2011, \text { Wiek et al. } 2011 \\
\text { ESD-discourse; Wiek, et al. 2011, } \\
\text { Barth et al. (2007), Bieberhofer, 2019, } \\
\text { Lackeus, 2020, Vare et al., 2006, } \\
\text { Giangrande, et al. 2019, Lans, 2014, } \\
\text { Rieckmann et al., (2018), UNESCO, } \\
\text { 2019, Ploum, et al., 2017 }\end{array}$ \\
\hline $\begin{array}{l}\text { Normative Competencies } \\
\text { Knowledge of the sustainability of } \\
\text { current and future states, knowledge/ } \\
\text { awareness of Ethics, fairness, } \\
\text { happiness,wellbeing,risk,tradeo } \\
\text { andethicalquestions }\end{array}$ & $\begin{array}{l}\text { Normative competency } \\
\text { Knowledge and the ability of } \\
\text { working with legislative, Ethical, } \\
\text { riskbbased, trade-tax and } \\
\text { production regulations as well as } \\
\text { accordance with own bbeliefs, } \\
\text { values and norms }\end{array}$ & $\begin{array}{l}\text { Entrepreneurship: Lackeus, 2020, } \\
\text { Bandura, 1997, Sarasvathy, 2001a, } \\
\text { 2001b, 2008, Blenker et al. 2011, Wiek } \\
\text { et al. 2011 } \\
\text { ESD-discourse; Barth et al. (2007), } \\
\text { Bieberhofer, 2019, Lackeus, 2020, } \\
\text { Vare et al., 2006, Giangrande, et al. } \\
\text { 2019, Lans, 2014, Rieckmann et al, } \\
\text { (2018), UNESCO, 2019, Ploum, et al., } \\
2017\end{array}$ \\
\hline $\begin{array}{l}\text { Anticipatory/ Forecasting } \\
\text { Competency } \\
\text { Scenariobuilding, - forecasting and } \\
\text { backcasting, intergenerational } \\
\text { equity, "what if" - imagination \& } \\
\text { creativity }\end{array}$ & $\begin{array}{l}\text { Anticipatory competency } \\
\text { The ability to work with and } \\
\text { analyze, foresee or creatively } \\
\text { visualize, predict, prevent build } \\
\text { scenarios, maps, customer-jour- } \\
\text { neys, trends and tendencies }\end{array}$ & $\begin{array}{l}\text { Entrepreneurship: Lackeus, 2020, } \\
\text { Bandura, 1997, Sarasvathy, 2001a, } \\
\text { 2001b, 2008, Blenker et al. 2011, Wiek } \\
\text { et al. } 2011 \\
\text { ESD-discourse; Barth et al. (2007), } \\
\text { Bieberhofer, 2019, Lackeus, 2020, } \\
\text { Vare et al., 2006, Giangrande, et al. } \\
\text { 2019, Lan, 2014, Rieckmann et al, } \\
\text { (2018), UNESCO, 2019, Ploum, et al., } \\
2017\end{array}$ \\
\hline $\begin{array}{l}\text { Intrapersonal (emotional) } \\
\text { Competency } \\
\text { Ability to handle contradictory } \\
\text { emotionsand thoughts } \\
\text { Personal and group stress management } \\
\text { Cultivating awareness. Finding inner } \\
\text { peace and compassion, meaning } \\
\text { making, Experiencing values, love } \\
\text { compassion and connection and } \\
\text { still maintain motivation }\end{array}$ & $\begin{array}{l}\text { Empathetic competency } \\
\text { The ability to understand and } \\
\text { relate personal capacities, } \\
\text { emotions and efforts in accord- } \\
\text { ance with own beliefs and handle } \\
\text { the emotional roller-coaster of } \\
\text { entre- and intrapreneurship }\end{array}$ & $\begin{array}{l}\text { Entrepreneurship: Nielsen et al. } \\
\text { 2009, Darsø 2011, FFE, 2013, } \\
\text { Sarasvathy, 2001a, 2001b, 2008, } \\
\text { ESD-discourse; Wiek et al. 2011, } \\
\text { Bieberhofer, 2019, Vare et al, 2006, } \\
\text { Giangrande, et al. 2019, UNESCO, } \\
\text { 2019, Ploum, et al., } 2017\end{array}$ \\
\hline Interpersonal Competencies & Self-awareness Competency & Entrepreneurship: Lackeus, 2020, \\
\hline $\begin{array}{l}\text { Selfreflection, personal insight } \\
\text { collaboration skills, role models } \\
\text { mediation, leadership, cooperation, } \\
\text { empathy, teamwork }\end{array}$ & $\begin{array}{l}\text { "Start with your means - Who am I - } \\
\text { Who do I know" the building of } \\
\text { short-term realistic goals, giving } \\
\text { immediate experience with dealing } \\
\text { with uncertainty in trying and } \\
\text { learning by doing. }\end{array}$ & $\begin{array}{l}\text { Bandura, 1997, Sarasvathy, 2001a, } \\
2001 \mathrm{~b}, 2008, \text { FFE, 2013, Blenker et al. } \\
2011 \\
\text { ESD-discourse; Wiek et al. 2011, } \\
\text { Bieberhofer, 2019, UNESCO, 2019, } \\
\text { Ploum, et al., } 2017\end{array}$ \\
\hline $\begin{array}{l}\text { Action-based opportunity } \\
\text { competencies } \\
\text { Developing and spotting value for } \\
\text { others-driven societal opportunities } \\
\text { and sustainale solutions, new } \\
\text { markets, trends and possible } \\
\text { collaborations }\end{array}$ & $\begin{array}{l}\text { Mastery competency } \\
\text { The ability to convert thoughts into } \\
\text { changeprovoking actions of value to } \\
\text { others }\end{array}$ & $\begin{array}{l}\text { Entrepreneurship: Lackeus, 2020, } \\
\text { Bandura, 1997, Saravasthy, 2003, } \\
\text { Kirketerp, Blenker, 2011, Sarasvathy, } \\
\text { 2001a, 2001b, 2008, } \\
\text { ESD-discourse; Vare, 2006, Frisk \& } \\
\text { Larsson, 2011, Ploum, et al, } 2017\end{array}$ \\
\hline $\begin{array}{l}\text { Entrepreneurial Self-efficacy } \\
\text { Successful sustainable experiences } \\
\text { with a given action before it } \\
\text { becomes a predominant pattern of } \\
\text { behaviour }\end{array}$ & $\begin{array}{l}\text { Self-efficacy competency } \\
\text { The use of a personal experienced } \\
\text { belief that future actions will } \\
\text { succeed: "Beliefs of personal efficacy } \\
\text { constitute the key factor of human } \\
\text { agency. If people believe they have } \\
\text { no power to produce results, they will } \\
\text { not attempt to make things happen" } \\
\text { (Bandura, 1997) }\end{array}$ & $\begin{array}{l}\text { Entrepreneurship: Bandura, } 1997, \\
\text { Saravasthy, 2001, Kirketerp, Blenker, } \\
2011, \\
\text { ESD-discourse; Ploum, et al, } 2017, \\
\text { Lans, } 2014, \text { Giangrande, 2019, } \\
\text { Bieberhofer, } 2019\end{array}$ \\
\hline
\end{tabular}

Figure 1 - Comparison of ESD Competencies with Entrepreneurship Competencies 
Based on the foregoing, this paper aims to analyse, explore and propose two tools to understand and measure students emotions. This knowledge can help create more engagement during learning processes, with special attention to the learning related to sustainability.

\section{Design and Entrepreneurship Didactics}

Design and entrepreneurship education are often characterised by trying to create real-time learning (design-methodology based) flows in time-pressured frameworks involving real stakeholders or collaborators. This kind of experiential learning (Kolb, 1984, p. 37) includes a process in which the student is taking charge of both the group and the individual's own learning, steering the process and still reaching their goals in a collaborative learning situation. This can involve challenges like "wicked problems", high levels of complexity and multiple layers of dilemmas in the problem-solving. All this can generate emotions impacting on the learning and self-development processes - sometimes exposing the student to the emotional extremes and bringing the student as close as possible to their personal limits, bringing into mind, educational psychology theory points at how developing a sense of performing valuable and controlled actions can improve the student motivation (Pekrun, 2006) These learning processes' could create new insights on a deeper level, such as "Who am I?", "What can I do?" and "What do I dare?". (Lackeus, 2017) At the same time, the present review of the definition of entrepreneurship as a "new value creation" could very well include the design-educations in a learning-orientated definition of entrepreneurship rather than opportunity-creation definitions. (Blenker et al., 2011). "When someone creates something that is both novel and valuable for others and when that person also learns and develops profoundly from the undertaking, people tend to label it as entrepreneurship". Lackeus (2020) describes the value-based entrepreneurship definition as "creating new kinds of value is a much broader activity type than creating a new organisation or a new business opportunity and can be seen in many people's "everyday practice" in all societal sectors" (Lackeus, 2020, p. 941).

Most of the research on entrepreneurship and design education has focused on how we make our students reflect -think- and perform -act- in terms of entrepreneurial or designerly behaviour. But lately, Lackeus $(2013,2016 a, 2017)$ has come up with a study of emotions as a potential indicator for the student's status and performance. Lackeus described three kinds of emotional events 1 . interaction with the outside world, 2 . uncertainty and ambiguity and 3. teamwork experience was linked to the student's entrepreneurial development.

By using a holistic and emotional view on entrepreneurial learning and competencies, Lackeus' studies show how emotional learning events are central in understanding how students become entrepreneurial and act towards the challenges facing them. The use of a variety of methodological strategies to discuss this with Higher Education students is crucial in developing new didactics for ESD. The basic principle is therefore using a participatory, democratic engaging evaluation of students' comprehension of how they perform and work with sustainable development in their studies and when designing. Both the Yggdrasill Concept and the Emotional Analogous Data Collection Kit uses participant observation -with the researcher as a lecturer- and dialogical learning (Meijers, 2009) and classroom ethnography (Owens, 2012) when employed. 


\section{Materials and methods}

\section{Method}

The research method that has been used for this article is considered one of the five experimentation methods of Research through Design, called Comparative. This method deals with acknowledging complexity, which expresses the idea that the design experiments explore the concept by pointing to how it is embedded in a multiplicity of situations. The reason for using the experimental method is in both theses to do case-relevant explorations, which cover areas and aspects not yet dealt with in other experiments and to incorporate knowledge from previous experiments. The method comprises a set of different emotional tools tried on two contexts -Via Design, Denmark and ELISAVA, Spain-. The basic approach is that each design experiment should reveal as yet undocumented additional qualities of a concept and confirm some previously found qualities.

In order to have a first idea on how to implement these two tools -Emotional Analogous Data and Yggdrasill, Emotionally Yours -a pilot study has been developed in these two university contexts. Specifically, a focus group comparative application.

\section{Participants and Procedure}

In order to use the Comparative method, voluntary students participated in this study, from both universities, with different profiles related to design, such as fashion design, furniture design, service design, innovation and design, product design, and product design engineering.

Different focus group sessions have been performed with the aim of comprehending the actual panorama/current scenario and having feedback to improve both tools.

In these focus group sessions, the same four questions have been asked to both users of Emotional Analogous Data and Yggdrasill and are as follows:

- Before knowing and testing the tool (name), have you ever considered emotions in the learning process?

- Has the tool (name) helped you to reflect on your own emotions in the educational context?

- What elements/parts of the tool (name) did you like the most?

- What elements/parts of the tool would you like to improve or change?

The data collection consisted of both semi-structured interviews with an anonymously written padlet for comments and reflections and an e-analyzer structured interview in Denmark (see figure 3); and with a live recorded interview in Spain.

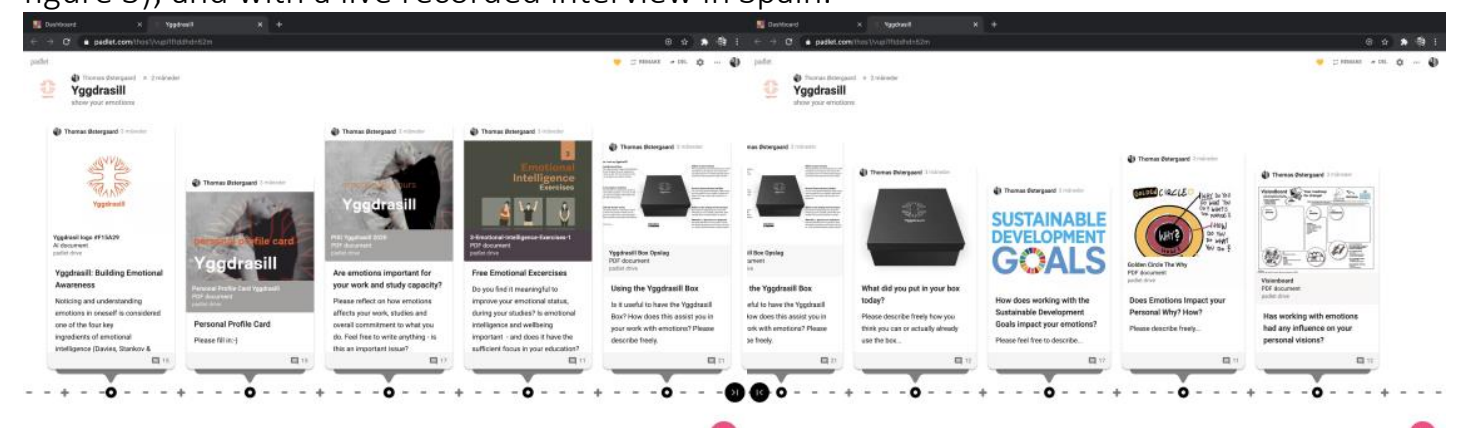

Figure 2 - Padlet interviews and comments from the students during the DFC-Yggdrasill course, 2020

125

Abella Garcia, Østergaard \& Araya

Futures of Education, Culture \& Nature - Learning to Become 


\section{Results: Emotional Tools}

As presented before, the aim of the present research is to understand how student's emotions and engagement can be measured during the learning process, to later apply in education for SDG. In the following sections, these two emotional tools are shown (see 4.1.) and the comparison in their application (see 4.2.).

\section{Emotional Tools}

Two emotional tools, Emotional Analogous Data and Yggdrasill, Emotionally Yours, have been designed in order to have self-reported measures. In the following sections, both tools are described.

\section{Emotional Analogous Data}

The Emotional Analogous Data (EAD) tool has been born as an exploratory path in the correlation of physical-environmental parameters, emotions, perception, well-being, and behaviour of people who develop an activity in a specific place. In its first application, the need to apply it to new case studies has been detected, as well as the opportunity to extend the research to other fields such as education (Araya et al., 2018).

To explore the tool in the educational context, in this case, be applied in the Master in Creative Process at Elisava, the EAD tool had been updated. The main transformation of the Emotional Analogous Data has been transformed into a structured notebook (see Figures 3 and 4), which allows being compiled with information related to perception and emotional states in a specific place.

The Emotional Analogous Data (EAD) is composed by:

- Basic data: age and gender.

- A general explanation of the use of the tool (see Figure 3).

- Environment and place perception kit (see Figure 4): Date, perception about space and furniture, emotional state at the beginning and the end of the activity/class, and score on the level of learning obtained. 


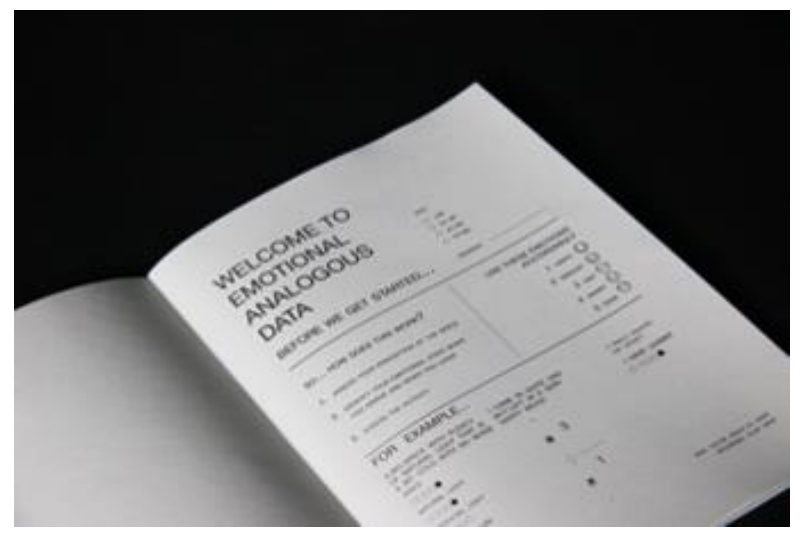

WELCOME TO

EMOTIONAL

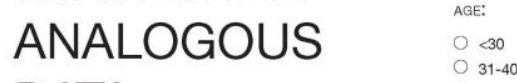

DATA

BEFORE WE GET STARTED...

\begin{tabular}{l|r}
\hline SO... HOW DOES THIS WORK? & USE THESE EMOTIONS \\
1. ASSESS YOUR PEACEPTION OF THE SPACE & 1 HAPPY \\
2. IDENTIFY YOUR EMOTIONAL STATE WHEN \\
YOU ARAIVE AND WHEN YOU LEAVE \\
3. ASSESS THE ACTIVITY
\end{tabular}

\begin{tabular}{|c|c|c|}
\hline \multicolumn{3}{|l|}{ FOR EXAMPLE... } \\
\hline $\begin{array}{l}\text { A BIG SPACE WITH PLENTY } \\
\text { OF NATURAL LIGHT THAT IS } \\
\text { A BIT COLD WITH NO NOISE }\end{array}$ & $\begin{array}{l}\text { I CAME IN QUITE SAD } \\
\text { BUTLEFT IN A VERY } \\
\text { HAPPY MOD }\end{array}$ & $\begin{array}{l}\text { I AEALLY ENJOYED } \\
\text { THE ACTIVITY }\end{array}$ \\
\hline $\begin{array}{l}\text { SPACE } \\
\text { OOOO }\end{array}$ & $\begin{array}{l}\text { HAPPY MOOD } \\
+\end{array}$ & $\begin{array}{l}\text { I HAVE LEARNT } \\
0000 \bullet\end{array}$ \\
\hline NATURAL LIGHT & 3 & \\
\hline $\begin{array}{l}\text { OOOO } \\
\text { AATIFICIAL LIGHT }\end{array}$ & $\underline{z}$ & \\
\hline $\begin{array}{l}\bullet \bullet 00 \\
\text { TEMPEAATUAE }\end{array}$ & $\div$ & \\
\hline $\begin{array}{l}\text { ๑OOO } \\
\text { NOISE LEVEL } \\
\bullet \circ O 00^{\circ}\end{array}$ & ₹ & \\
\hline $\begin{array}{l}\text { FUFNTURE CONFORT } \\
\text { OOOOO }\end{array}$ & - & $\begin{array}{l}\text { NOW YOU'AE READY TO STAAT } \\
\text { RECOAONNG YOUR DATA! }\end{array}$ \\
\hline
\end{tabular}

Figure 3 - General explanation of the use of Emotional Analogous Data (EAD). 

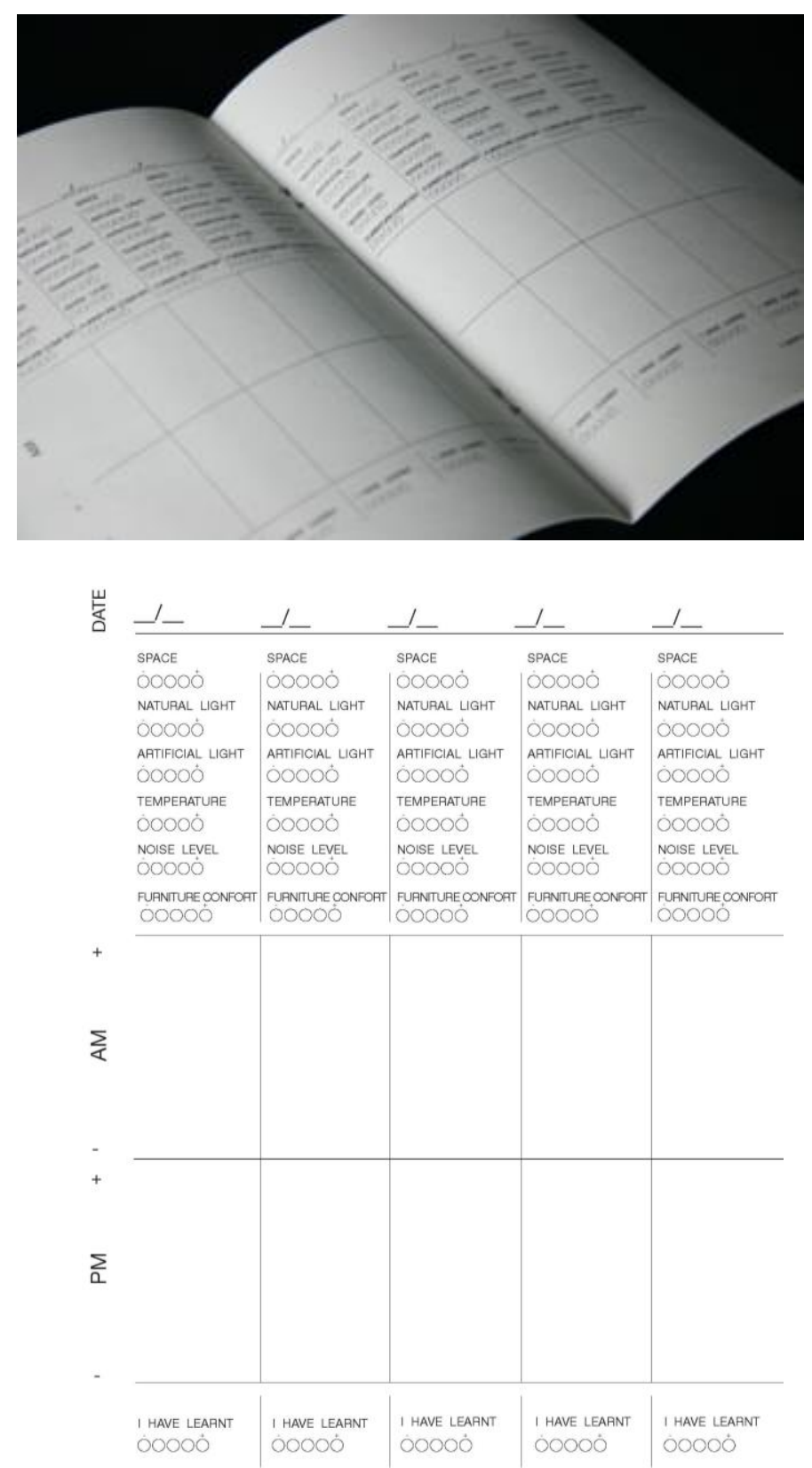

Figure 4 - Environment and place perception kit from Emotional Analogous Data (EAD).

In this version applied to the educational context, participants must be students of any university degree. The specific places can be classrooms, laboratories, and libraries, among others.

The tool is given, at the beginning of their academic calendar, to each participant to be tested in one subject. The academic staff teaches them how to use it and reminds them to fill it in all activities, independent of the place. The objective is to evaluate and compile their perception and their emotional states of the moment during the learning process. 


\section{Yggdrasill, Emotionally Yours}

Yggdrasill wishes to implement a new didactical approach to teaching designers how to be aware of how emotions impact our dedication and our development of competencies over a time span of 2 years. Yggdrasill consists of four core elements:

1. A new experimental framing of teaching, in which emotions can work as accepted enhancers as well as restrainers of sustainable (SDG) learning, for both students and teachers, including a "manual - description". (Emotional Learning)

2. A personal Yggdrasill Box providing students and teachers a reflection tool and frame for conversations about emotions, memories and learning processes.

3. An open process as a series of emotional surveys (diaries, padlet and enalyzer) which will try to establish an understanding of how we can use an understanding of emotional learning in the future.

4. The establishment of a durable, long-term relationship between the student, an emotional object (the box) and the teaching/institution and its academic facilitators.

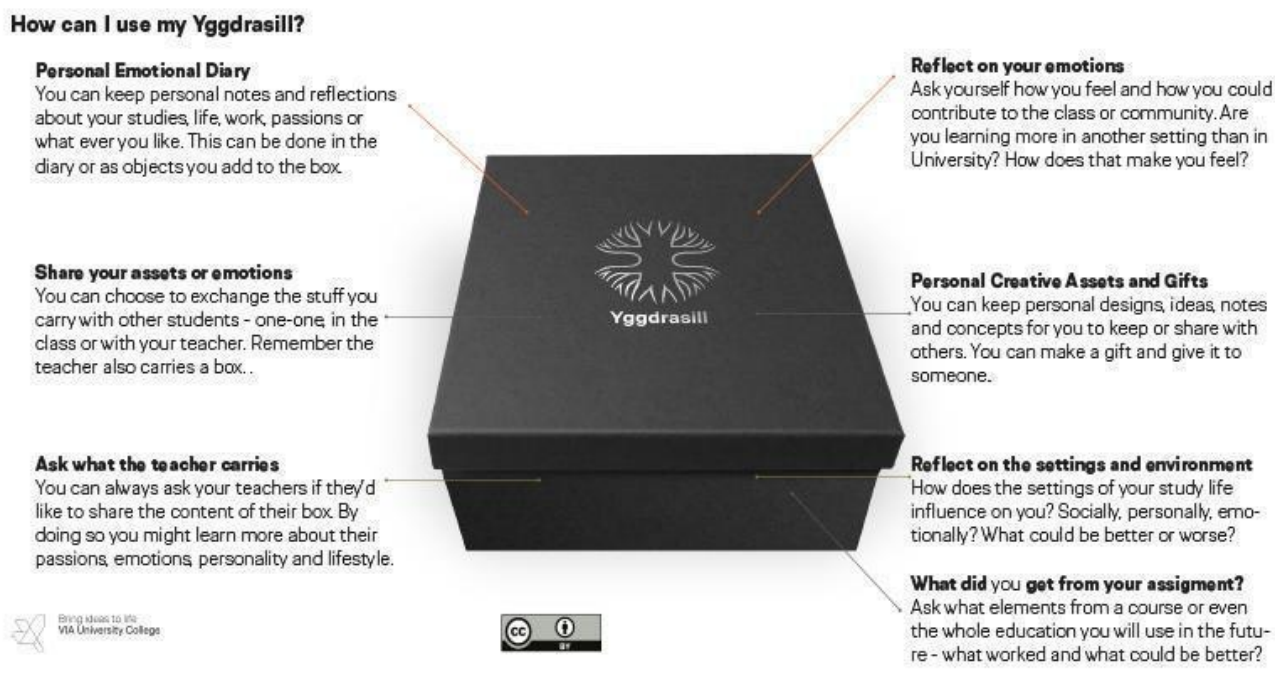

Figure 5 - The Yggdrasill Box, illustrated and exemplified use for the student.

\section{Comparison of application of Emotional Tools}

In order to improve both tools and compare them, different focus group sessions were held at two universities. To do so, the same four questions were asked to all volunteers. The main results from both tools are grouped by a question:

Question 1: Before knowing and testing the tool (name), have you ever considered emotions in the learning process?

Some of the students have considered emotions during one's personal learning, especially how they feel when some topic generates joy or frustration on them, and also about the relationship between emotional well-being and efficiency. Another relevant aspect of emotions is mental balance and the optics through which one interprets the outside world. But none of them have taken into account how the space and stimulus around them could impact their well-being and predisposition for learning. 


\section{Question 2: Has the tool (name) helped you to reflect on your own emotions in the educa- tional context?}

In all cases, the tool has helped them to reflect, think and remember their emotions and some parameters, such as noise and the typology of the classroom, that could affect concentration and motivation for learning while they were using the tool. Some of them after this period still apply the tool or think about the emotions, and while the rest have stopped after the pilot study has finished.

\section{Question 3: What elements/parts of the tool (name) did you like the most?}

The dynamisation of the tool promotes reducing the formal distance between teacher and student, since it increases the willingness to learn and mutual respect.

Some environment parameters, like temperature and typology of light -natural or artificialbecause it helps to understand and make more conscious of these parameters that affect wellbeing and disposition on the place.

\section{Question 4: What elements/parts of the tool would you like to improve or change?}

Some environmental parameters are difficult to evaluate because some students doubt if the evaluation is related to the parameter or the preference and like of the parameter.

Furniture comfort has been understood as having two different meanings, the first one related to comfort and the second one related to the quantity and vital space in order to feel well to do the tasks.

On the other hand, new parameters have been suggested in order to improve the tools, such as the interaction between people and the flow of ideas.

Apart from tool feedback, some recommendations to apply them or the dynamisation during the application, some of the main results are:

- During the classroom, give some time to fill up data.

- Coordinate and explain to all the teachers the activity to promote it.

- Give more importance and insist on returning the results.

- Another format, such as including the tool into the University's App - Elisava Life.

- Give a good explanation to all students to avoid misunderstanding.

\section{Discussion and First Conclusions}

Lately, the importance of engaging with experts on human behaviour (i.e., psychologists) in order to create behavioural change in the SDG direction has been recognised. But integrating psychology into the curricular of SDG/ESD is still very scarce. Results confirm the previous information as some students are not used to relating to their own emotions and how their educational environment influences their own well-being.

Consequently, most design majors are graduating with no background in applying the field to promoting sustainability, and ESD-design students lack explicit education focused on understanding and changing human behaviour. If the HE's wish to implement a sustainable educational framework, research in ESD promotes the focus on personality development, thus enabling a person to cope with complexity, uncertainty, act upon own reflection and responsible, ethical decision-making. A "New Learning Culture" is characterised on the basis of three needs: (Barth, et al. 2007; Østergaard, 2019,p. 16; Bason, 2010; Manzini, 2016)

A: Competence-orientation: The focus of the learning processes should be on providing relevant key competencies to the students. Providing an open and involving didactic framework is necessary offering reflection possibilities for developing personal competencies and can help to identify possible personal and collaborative learning assets. 
B: Societal orientation: Learning for SD is fundamentally societal learning, which should take place in and with real case-collaborations and include systemic teaching and understanding.

C: Individual and Emotional Learning Centring: Individual learning is considered to be an asset in a societal orientation. In formal contexts of learning, it changes the role of the teacher towards being a facilitator of learning with the students.

In addition to this, the HE's need to find ways of innovating new methods, tools or realms of interaction, which can integrate and use the knowledge and competencies developed in informal learning settings, as students not only learn in formal settings. Especially "experiential learning", as a form of informal emotional learning, plays a central role in developing competencies, as it is a part of a person's activities and emotions are a key element for any learning. Experiential learning can facilitate the development of action competencies and has special importance for developing "life competency", meaning the capacity to act on, plan and implement individual or common life-projects.

By implementing the emotional aspects into the didactics, deriving from Lackeus' three emotional events (1. interaction with the outside world, 2. Working with uncertainty and ambiguity and 3. teamwork experience) can enhance and foster the students emotional entrepreneurial development. As competencies are descriptive for a person's capability of acting, competencies do not ensure actual action of the intended competency. And this is a little tricky, as sustainability-oriented performances are highly dependent on how knowledge, skills, values, motivational and emotional drivers, and opportunities interact. The world needs action - competencies and knowledge. Some of the foremost researchers in this field have made suggestions to adapt entrepreneurial methodologies to enhance the formation of sustainable entrepreneurs of the future.

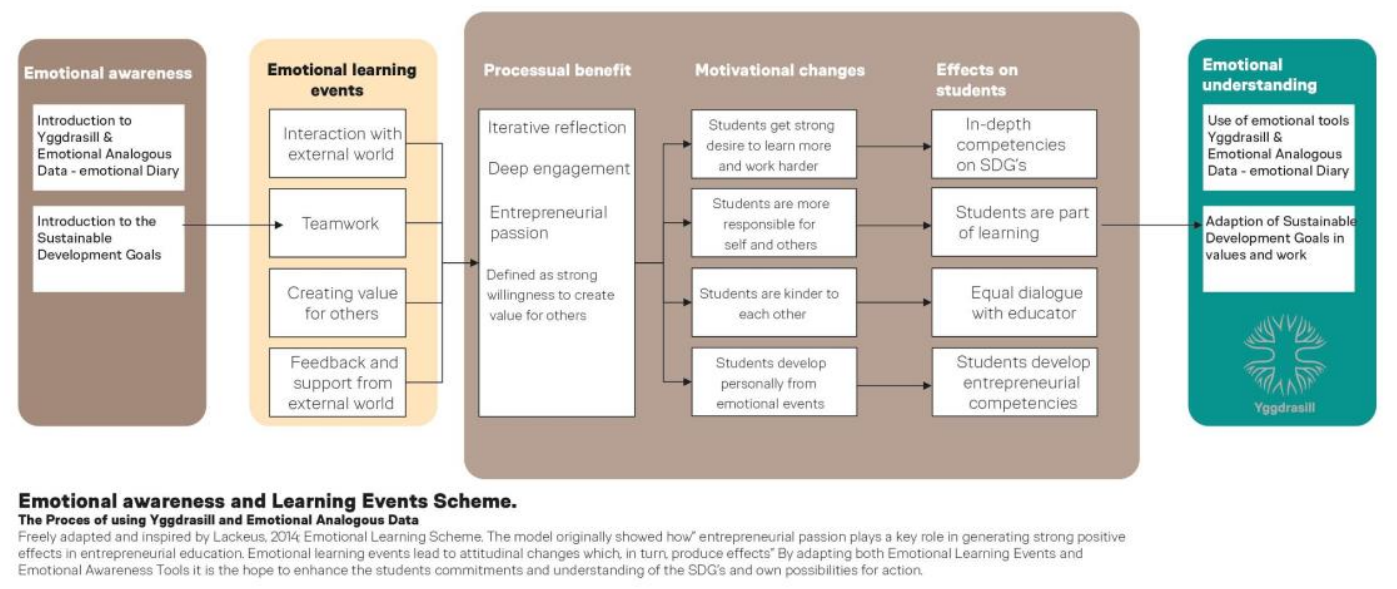

Figure 6 - Visualisation of how education could integrate Emotional awareness and Learning Events Scheme adapted from Lackeus' model for Emotional Entrepreneurial Events, (2016).

As a profound revision of the knowledge-based, consumption and growth paradigms, it is crucial design-schools redefine their roles and take part by including ecological, social, sustainable values in their base of the curriculum. The real challenge for design-schools and universities is how to develop new frameworks of formal and informal learning methods through which students can acquire key competencies in support of sustainable actions. The experimental ESD projects described in this article are both new but hopefully also useful reflection frameworks for progressive dialogue and informally extra-curricular based experiential learning. As the projects are still in an ongoing evolution of competencies, some of the findings from the research in the ESD discourse can be applied in the future. 


\section{Limitations and Future Research}

In the development of this study, limits related to the subject of emotions have been found, on the one hand, the little knowledge on the part of the students in the identification of them and the large number of existing theories. In addition, emotions can have a cultural connotation, and in this case study, the tools are applied in two very different contexts.

As future avenues for this research, the authors of this chapter propose to extend the application of a mix of emotional and entrepreneurial didactical tools to students in the future, even with the incorporation of teaching staff, since it is a fundamental part of this emotional dimension. On the other hand, it would also be relevant to understand new formats and dynamics for these tools to promote their application in other contexts and be more engaging for all generations of students.

\section{Literature}

Abella Garcia, A., Clèries, L. \& Marco-Almagro, LI. (2020). Framework of Emotional Dimensions: Definitions, Theories, and Measuring Tools for Design. The International Journal of Design Management and Professional Practice, 13(3), 13-29. https://doi.org/10.18848/2325162x/cgp/v13i03/13-29

Abella, A, Clèries, L, \& Marco-Almagro, LL. (2019). Mapeo preliminar del diseño y la emoción: convergencias para la conciencia social y ambiental. Academia XXII, 10 (19): 100-121. http://dx.doi.org/10.22201/fa.2007252Xp.2019.19.69890

Araya, M. J., Abella, A., Guasch, R., Estevez, A., \& Peña, J. (2019). Emotional Analogous Data: Interacción en el espacio laboral. Intersecciones Congress, 718-733. Chile.

Barth, M., Godemann, J., Rieckmann, M., \& Stoltenberg, U. (2007). Developing Key Competencies for Sustainable Development in Higher Education. International Journal of Sustainability in Higher Education, 8(4), 416-430.

https://doi.org/10.1108/14676370710823582

Batson, C. D., Duncan, B. D., Ackerman, P., Buckley, T., \& Birch, K. (1981). Is empathic emotion a source of altruistic motivation?. Journal of personality and Social Psychology, 40(2), 290302. https://doi.org/10.1037/0022-3514.40.2.290

Biberhofer, P., Lintner, C., Bernhardt, J. \& Rieckmann, M. (2019). Facilitating work performance of sustainability-driven entrepreneurs through higher education - The relevance of competencies, values, worldviews and opportunities. The International Journal of Entrepreneurship and Innovation, 20 (1), 21-38. https://doi.org/10.1177/1465750318755881

Chapman, J. (2015). Emotionally Durable Design: Objects, Experiences and Empathy. Londres: Routledge.

Giangrande, N., White, R. M., East, M., Jackson, R., Clarke, T., Saloff Coste, M., \& Penha-Lopes, G. (2019). A competency framework to assess and activate education for sustainable development: Addressing the UN sustainable development goals 4.7 challenge. Sustainability, 11(10), 2832. https://doi.org/10.3390/su11102832

Kolb, D. (1984). Experiential Learning as the Source of Learning and Development. Englewood Cliffs: Prentice Hall International.

Lackéus, M. (2013). Links between Emotions and Learning Outcomes in Entrepreneurial Education Conference paper at 22nd Nordic Academy of Management conference (NFF), Reykjavik, Iceland, 21-23 of August 2013. 
Lans, T., Blok, V., \& Wesselink, R. (2014). Learning apart and together: towards an integrated competence framework for sustainable entrepreneurship in higher education. Journal of Cleaner Production, 62, 37-47. https://doi.org/10.1016/j.jclepro.2013.03.036

Larruzea-Urkixo, N., Cardeñoso, M. O., \& Mondragon, N. I. (2020). El alumnado del Grado de Educación ante las tareas universitarias: emoción y cognición [The students of the Degree of Education before the university tasks: emotion and cognition]. Educación XXI [Education XXI], 23(1). https://doi.org/10.5944/educxx1.23453

Laverie, Debra A., Robert E. Kleine III, \& Susan S. Kleine. (1993). Linking Emotions and Values in Consumption Experiences: an Exploratory Study. Advances in Consumer Research, 20, 70-75.

LeDoux, J. E. (1992). Brain Mechanisms of Emotion and Emotional Learning. Current Opinion in Neurobiology, 2 (2): 191-97. https://doi.org/10.1016/0959-4388(92)90011-9

Oatley, K., \& Johnson-Laird, P. N. (1987). Towards a Cognitive Theory of Emotions. Cognition and Emotion, 1(1), 29-50. https://doi.org/10.1080/02699938708408362

Ortony, A., \& Turner, T. J. (1990). What's basic about basic emotions? Psychological Review, 97(3), 315-331. https://doi.org/10.1037/0033-295X.97.3.315

$\varnothing$ stergaard, T. (2019). Revising Creative Sustainability-competencies in Design Educations: The Future of Design. In Decoding European Creative Skills: The Future of Design (pp. 13-19). ELISAVA.

Pekrun, R. (2014). Emotions and learning: Educational practices series-24. Belley: International Academy of Education.

Ploum, L., Blok, V., Lans, T., \& Omta, O. (2018). Toward a validated competence framework for sustainable entrepreneurship. Organization \& environment, 31(2), 113-132. https://doi.org/10.1177/1086026617697039

Rodrigo-Ruiz, D. (2016). Effect of teachers' emotions on their students: Some evidence. Journal of Education \& Social Policy, 3(4), 73-79.

Rychen, D. S., \& Salganik, L. H. (2003). Key competencies for a successful life and well-functioning society. Boston: Hogrefe Publishing.

Vare, P., \& Scott, W. (2007). Learning for a Change: Exploring the relationship between education and sustainable development. Journal for Education for Sustainable Development, 1(2), 191-198. https://doi.org/10.1177/097340820700100209

Wiek, A., Withycombe L., \& Redman, C.L. (2011). Key Competencies in Sustainability: A Reference Framework for Academic Program Development. Sustainability Science 6(2), 203218. https://doi.org/10.1007/s11625-011-0132-6 